\title{
Chemical Composition and Antimicrobial Activity of Essential Oils from Xylopia aromatica (Annonaceae) Flowers and Leaves
}

\author{
Nascimento, M. N. G.; Junqueira, J. G. M.; Terezan, A. P.; Severino, R. P.; \\ Silva, T. S.; Martins, C. H. G.; Severino, V. G. P.*
}

Rev. Virtual Quim., 2018, 10 (5), 1578-1590. Data de publicação na Web: 09 de outubro de 2018

http://rvq.sbq.org.br

\section{Composição Química e Atividade Antimicrobiana dos Óleos Essenciais das Flores e Folhas de Xylopia aromatica (Annonaceae)}

\begin{abstract}
Resumo: Os óleos essenciais (OE) das flores e folhas foram obtidos por hidrodestilação e analisados por cromatografia gasosa acoplada à espectrometria de massa (CG-EM). Os principais compostos identificados no OE das flores foram: pentadecan-2-ona $(16,38 \%)$, biciclogermacreno $(9,74 \%)$, 7-epi- $\alpha$-eudesmol $(7,76 \%)$, khusinol $(7,23 \%)$, $n$-tricosano $(6,17$ $\%)$, heptadecan-2-ona (5,83\%), geranil- $\alpha$-terpineno (4,46\%) e cedr-8(15)-en-9 $\alpha$-ol (4,40\%). O OE das folhas apresentou predominantemente espatulenol $(27,11 \%)$, khusinol $(13,04 \%)$, biciclogermacreno $(8,52 \%)$, globulol $(6,47 \%)$, cis-guaia-3,9dien-11-ol (5,98\%), 2-epi- $\alpha$-cedren-3-ona (4,69 \%) e elemicina (4,32\%). A atividade antimicrobiana dos óleos essenciais foi testada em cepas bacterianas Gram-positivas e Gram-negativas, além de fungos. As menores concentrações inibitórias mínimas (CIM) foram observadas frente à Streptococcus pyogenes ATCC 12345 (200 e $100 \mathrm{\mu g} \mathrm{mL}^{-1}$ ) para as flores e folhas, respectivamente. Quanto ao potencial antifúngico, o OE das folhas apresentou atividade moderada (500 $\left.\mu \mathrm{g} \mathrm{mL}^{-1}\right)$ frente à Candida albicans. Em suma, este estudo reporta dados sobre a composição química e atividade antimicrobiana do OE de flores $X$. aromatica, contribuindo para o conhecimento sobre esta espécie
\end{abstract}

Palavras-chave: Xylopia aromatica; flores; óleo essencial; CG-EM; atividade antimicrobiana.

\begin{abstract}
The essential oils (EO) from flowers and leaves were obtained by hydrodistillation and analyzed by gas chromatographymass spectrometry. The main compounds found in the flower oil were pentadecan-2-one (16.38\%), bicyclogermacrene (9.74 $\%)$, 7-epi- $\alpha$-eudesmol (7.76\%), khusinol (7.23\%), $n$-tricosane (6.17\%), heptadecan-2-one (5.83\%), geranyl- $\alpha$-terpinene (4.46 $\%)$ and cedr-8(15)-en-9 $\alpha$-ol (4.40\%). The leaf oil contained predominantly spathulenol (27.11\%), khusinol (13.04 \%), bicyclogermacrene (8.52\%), globulol (6.47\%), cis-guaia-3,9-dien-11-ol (5.98\%), 2-epi- $\alpha$-cedren-3-one (4.69\%) and elemicin (4.32\%). The antimicrobial activity of the EO was tested against Gram-positive and Gram-negative bacterial strains and fungi. The flower and leaf oils exhibited the lowest minimum inhibitory concentrations (MIC) against Streptococcus pyogenes ATCC 12345 (200 and $100 \mu \mathrm{g} \mathrm{mL}^{-1}$ respectively). As for antifungal potential, the EO from leaves showed moderate activity (500 $\mu \mathrm{g}$ $\mathrm{mL}^{-1}$ ) against Candida albicans. This study offers the first report about the chemical composition and antimicrobial activity of the EO from $X$. aromatica flowers and contributes to the body of knowledge about this species.
\end{abstract}

Keywords: Xylopia aromatica; flowers, essential oil; GC-MS; antimicrobial activity.

\footnotetext{
* Universidade Federal de Goiás, Instituto de Química, Regional Goiânia, Campus Samambaia, CEP 74690-900, Goiânia-GO, Brasil.

$M$ vanessa.pasqualotto@pq.cnpq.br

DOI: $\underline{10.21577 / 1984-6835.20180107}$
} 


\section{Chemical Composition and Antimicrobial Activity of Essential Oils from Xylopia aromatica (Annonaceae) Flowers and Leaves}

\section{Michelle N. G. do Nascimento, ${ }^{a}$ João Gabriel M. Junqueira, ${ }^{a}$ Ana Paula Terezan, ${ }^{a}$ Richele Priscila Severino, ${ }^{a}$ Thayná de Souza Silva, ${ }^{b}$ Carlos Henrique G. Martins, ${ }^{\text {b }}$ Vanessa G. P. Severino ${ }^{c}$}

${ }^{a}$ Federal University of Catalão, Department of Chemistry, Lamartine Pinto de Avelar avenue 1120, CEP 75704-020, Catalão, Brazil.

${ }^{b}$ Franca University, Laboratory of Research and Applied Microbiology, Armando Salles de Oliveira avenue 201, CEP 14404-600 Franca, Brazil.

' Federal University of Goiás, Institute of Chemistry, Regional Goiânia, Campus Samambaia, Esperança avenue, CEP 74690-900 Goiânia, Brazil

* vanessa.pasqualotto@pq.cnpq.br

Recebido em 16 de julho de 2018. Aceito para publicação em 25 de setembro de 2018

1. Introduction

2. Experimental Section

2.1. Plant material

2.2. Obtaining Essential Oil

2.3. GC-MS Analysis

2.4. Identification of the constituents of essential oils

2.5. Determination of the antimicrobial activity

\section{Results and Discussion}

3.1. Chemical composition of essential oil from $X$. aromatica flowers and leaves

3.2. Antimicrobial Activity

\section{Conclusions}

\section{Introduction}

The genus Xylopia is one of the most important ones in the Annonaceae family. ${ }^{1}$ It comprises approximately 160 species widely distributed in tropical and subtropical regions of the Americas, Africa, Asia and Oceania. From a chemical point of view, this genus has been extensively studied because of its numerous odoriferous species. ${ }^{2}$ Recent studies on the evaluation of chemical composition of essential oils (EO) in Xylopia species (i.e $X$. frutescens, $X$. sericea, $X$. brasiliensis, $X$. nitida and $X$. langsdorffiana) have been reported. The major compounds found in the EO from $X$. brasiliensis leaves were spathulenol (40.8\%), 1,8-cineole (11.1 
$\%)$ and verbenone (11.1\%). ${ }^{3}$ From the EO of $X$. nitida leaves $p$-cymene $(24.6 \%)$ and $\beta$ caryophyllene $(21.4 \%)$ were the predominant constituents found. ${ }^{4}(E)$-caryophyllene (31.5 $\%)$, bicyclogermacrene (15.1\%), germacrene D (9.7\%), o-cadinene (5.4\%), viridiflorene (5.1 $\%)$ and $\alpha$-copaene (4.4\%) were reported from the leaves of $X$. frutescens with anticancer activity. ${ }^{5}$ The constituents of the EO from the leaves of $X$. langsdorffiana also availed the presence of germacrene $D(22.9 \%)$, trans- $\beta$ caryophyllene $(15.7 \%)$ and $\alpha$-pinene $(7.3 \%)$ with molluscicidal activity. ${ }^{6}$ Finally, in the EO composition of $X$. sericea fruits there were cubenol (57.4\%) and $\alpha$-epi-muurolol (26.1 \%), which presented acaricidal activity. ${ }^{7}$

Xylopia aromatica (Lam.) Mart., popularly known as "pimenta-de-macaco," is a small tree (4-5 m tall) commonly occurring in Brazil's coastal forests and savannas (Cerrado). ${ }^{8}$ This plant is widely cultivated because of its attractively scented white flowers and its use in folk medicine as a carminative, stimulant, diuretic, treatment of digestive diseases and spice for seasoning meat. ${ }^{9,10}$ The leaves, fruit and stem bark have already been studied by analyzing their essential oils (EO). ${ }^{2,9,11}$ However, the constituents of the EO of $X$. aromatica flowers have not yet been determined, and so far only the floral scent has been examined. ${ }^{12,13}$

With respect to its biological action, the insecticidal activity and antiseptic and analgesic properties of various Xylopia spp. extracts have been reported. ${ }^{8}$ The bacteriostatic and fungistatic activities of EO from the stem bark and leaves of $X$. aromatica against some microorganisms have also been determined. ${ }^{10}$ However, to date, no information is available about the antimicrobial activity of the EO of its flowers.

In this work, a variety of microorganisms that cause skin disorders were selected to evaluate the antimicrobial activity of the aromatic essential oil of $X$. aromatica. These microorganisms include Staphylococcus aureus, Streptococcus pyogenes and Propionibacterium acnes, which are Grampositive bacteria that can cause disorders ranging from pharyngitis and mild skin infections (such as impetigo) to serious infections such as scarlet fever ${ }^{14}$ and infective endocarditis, resulting in considerable global human morbidity and mortality. ${ }^{15}$

Pseudomonas aeruginosa and Burkholderia cepacia are Gram-negative bacteria associated with infections that include pneumonia, bacteremia, skin and soft tissue infection and genitourinary tract infection. ${ }^{16,17}$ Almost $10 \%$ of all hospitalacquired infections are caused by $P$. aeruginosa, which kills thousands of people every year. ${ }^{18}$

Candida species are opportunistic pathogens that have been considered the second most frequent cause of fungal infections in humans worldwide. ${ }^{19,20}$ To date, there are no vaccines against any fungal pathogens. Only a few antifungal agents are in clinical use and therapies are limited by drugsafety considerations. ${ }^{20,21}$

This paper offers the first report of the composition and antimicrobial effect of EO of $X$. aromatica flowers. Previous studies have investigated the antimicrobial activity of EO of $X$. aromatica leaves against $S$. aureus, Mycobacterium smegmatis, Escherichia coli, $P$. aeruginosa and $C$. albicans; ${ }^{10}$ here, we report the activity of this EO against $B$. cepacia, S. pyogenes, $P$. acnes and C. tropicalis for the first time. In addition, the chemical composition of the leaf oil is analyzed and compared with results of previous studies.

\section{Experimental Section}

\subsection{Plant material}

$X$. aromatica flowers and leaves were collected in the mornings, the former in October 2014 and the latter in February 2015, at the Federal University of Goiás in Catalão city. The leaves were collected randomly, while the flowers selected were those with open corolla (both obtained from fully developed specimens). The species was identified and a voucher was deposited at the 
Centro-Norte-Matogrossense Herbarium of the Federal University of Mato Grosso - UFMT - Campus Sinop, under number 6554.

\subsection{Obtaining essential oil}

Fresh $X$. aromatica flowers and leaves (300 $\mathrm{g}$ each) were subjected to hydrodistillation for $4 \mathrm{~h}$ in a Clevenger-type water steam distillation apparatus. The oil thus collected was dried over anhydrous sodium sulfate, resulting in strong-smelling pale-yellow oil in yields of 0.2 and $0.1 \%(w / w)$ from flowers and leaves, respectively, that was stored at $7{ }^{\circ} \mathrm{C}$ until analysis. All the experiments were carried out in triplicate.

\subsection{GC-MS analysis}

The EO from flowers was analyzed in a gas chromatograph (Agilent Technologies, 7820 A) coupled to a mass spectrometer (MSD 5975, Agilent Technologies, USA), equipped with a non-polar HP-5 MS fused silica capillary column $(30 \mathrm{~m} \times 0.250 \mu \mathrm{m}, 0.25 \mu \mathrm{m}$ film thickness; Agilent). The EO from leaves was analyzed in a gas chromatograph coupled to a mass spectrometer (Shimadzu GC-MS QP5000), equipped with a DB-5 MS capillary column $(30 \mathrm{~m} \times 0.250 \mu \mathrm{m}, 0.25 \mu \mathrm{m}$ film thickness). The injector, interface, ionization source and quadrupole temperatures were $250,280,230$ and $150^{\circ} \mathrm{C}$, respectively, in the two devices. Helium was used as the carrier gas at a flow rate of $1 \mathrm{~mL} \mathrm{~min}-1$ and a split ratio of $10: 1$. The injection volume was $1 \mu \mathrm{L}$ of diluted solution $(1 / 1000)$ of oils in $n$-hexane. The column temperature was set from $60^{\circ} \mathrm{C}$ (2 min) to $250{ }^{\circ} \mathrm{C}$ at a heating rate of $4{ }^{\circ} \mathrm{C} \mathrm{min}^{-}$ ${ }^{1} ; 250^{\circ} \mathrm{C}$ (10.5 min). MS spectra were obtained using electron impact at $70 \mathrm{eV}$, a scan interval of $3.46 \mathrm{~s}$, and fragments from 45 to 450 u.m.a.

\subsection{Identification of the Constituents of Essential Oils}

The chemical constituents were identified based on the Kovats index (KI), which was determined in relation to a homologous series of $n$-alkanes $\left(C_{8}-C_{30}\right)$ run under the same operating conditions, as well as comparisons with authentic compounds. The KI obtained was compared with $\mathrm{KI}$ of the NIST Standard Reference Data ${ }^{22}$ and the Adams book. ${ }^{23}$ In addition, comparison of the mass spectra and their similarity index to those stored in the libraries was applied (Nist08, Wiley139, Wiley 229, ShimDemo, and Shim2205 libraries) or to mass spectra reported in the literature. ${ }^{22,23}$

\subsection{Determination of the Antimicrobial Activity}

The antimicrobial activity of the EO samples from $X$. aromatica flowers and leaves was evaluated against: a) five strains of Grampositive bacteria (Staphylococcus aureus ATCC 29213, S. aureus ATCC 25923, S. aureus ATCC 43300, Streptococcus pyogenes ATCC 12345 and Propionibacterium acnes ATCC 11827); b) three strains of Gram-negative bacteria (Pseudomonas aeruginosa ATCC 14502, P. aeruginosa ATCC 27853 and Burkholderia cepacia ATCC 17759); and c) two strains of fungi (Candida albicans ATCC 4639 and C. tropicalis ATCC 13803).

The MIC values were found to be the lowest concentrations that prevented visible growth, using the broth microdilution method in 96-well microplates described previously. ${ }^{24,25}$ The samples were tested at concentrations ranging from 0.195 to $400 \mu \mathrm{g}$ $\mathrm{mL}^{-1}$. After incubation period, $30 \mu \mathrm{L}$ of an aqueous solution of $0.02 \%$ resazurin (SigmaAldrich) was added to each well. Resazurin is an oxidation reduction probe that allows for immediate observation of microbial growth. The blue and red colors represent the absence and presence of microbial growth, respectively. ${ }^{26}$ 


\section{Results and Discussion}

\subsection{Chemical Composition of Essential Oil from $X$. aromatica Flowers and Leaves}

The EOs of $X$. aromatica were obtained by hydrodistillation in yields of 0.2 and $0.1 \%$ $(\mathrm{w} / \mathrm{w})$ from flowers and leaves, respectively. The results of this chemical analysis are presented in Tables 1 and 2. The twenty-eight constituents identified in the oils from flowers are listed in Table 1. Sesquiterpenes represented the main class $(68.94 \%)$ of detected compounds. The main sesquiterpenes were bicyclogermacrene (9.74 $\%)$, zonarene $(2.90 \%)$ and $\delta$-cadinene $(2.40$ $\%)$, while 7-epi- $\alpha$-eudesmol (7.76\%), khusinol (7.23\%) and cedr-8(15)-en-9 $\alpha$-ol (4.40\%) were the main oxygenated sesquiterpenes. However, the major constituent identified in this oil was pentadecan-2-one (16.38\%). Ketones correspond to $10.34 \%$ of volatile crude oil. Among other compounds, considerable amounts of $n$-tricosane $(6.17 \%)$, heptadecan-2-one (5.83\%), geranyl- $\alpha$ terpinene $(4.46 \%)$, cubenol (3.44\%), globulol $(3.13 \%)$ and spathulenol (3.00\%) were detected.

Table 1. Chemical constituents of the essential oil from $X$. aromatica flowers

\begin{tabular}{|c|c|c|c|c|c|}
\hline \multirow[b]{2}{*}{$R_{t}(\min )$} & \multirow[b]{2}{*}{ Compound $^{1}$} & \multicolumn{2}{|c|}{ KI } & \multirow{2}{*}{$\begin{array}{c}\text { Area } \\
\text { (\%) }\end{array}$} & \multirow[b]{2}{*}{ Criteria } \\
\hline & & Calculated $^{2}$ & $\begin{array}{c}\text { Literatur } \\
\text { e }\end{array}$ & & \\
\hline 15.81 & neral & 1245 & 1238 & 1.51 & $a, c$ \\
\hline 18.93 & $\delta$-elemene & 1340 & 1338 & 0.76 & $a, b, c$ \\
\hline 23.49 & germacrene D & 1485 & 1485 & 1.33 & $a, b, c$ \\
\hline 23.97 & bicyclogermacrene & 1501 & 1500 & 9.74 & $a, b, c$ \\
\hline 24.54 & $\delta$-cadinene & 1520 & 1523 & 2.40 & $a, b, c$ \\
\hline 24.76 & zonarene & 1527 & 1529 & 2.90 & $a, b, c$ \\
\hline 26.38 & spathulenol & 1581 & 1578 & 3.00 & $a, b, c$ \\
\hline 26.56 & globulol & 1587 & 1590 & 3.13 & $a, b, c$ \\
\hline 26.79 & viridiflorol & 1595 & 1592 & 1.93 & $a, b, c$ \\
\hline 26.96 & guaiol & 1600 & 1600 & 1.36 & $a, b, c$ \\
\hline 27.10 & 5-epi-7-epi- $\alpha$-eudesmol & 1605 & 1607 & 0.90 & a, c \\
\hline 27.23 & $\beta$-atlantol & 1610 & 1608 & 1.70 & $a, b, c$ \\
\hline 27.41 & isolongifolan-7- $\alpha$-ol & 1617 & 1619 & 1.14 & $a, c$ \\
\hline 27.61 & unknown 1 & 1624 & - & 2.32 & - \\
\hline 27.82 & cis-cadin-4-en-7-ol & 1632 & 1636 & 2.52 & $a, c$ \\
\hline 28.22 & cubenol & 1646 & 1646 & 3.44 & $a, b, c$ \\
\hline 28.28 & cedr-8(15)-en-9 $\alpha$-ol & 1649 & 1651 & 4.40 & a, c \\
\hline 28.46 & $\alpha$-eudesmol & 1655 & 1653 & 1.68 & $a, b, c$ \\
\hline 28.56 & 7-epi- $\alpha$-eudesmol & 1659 & 1663 & 7.76 & $a, b, c$ \\
\hline 28.80 & ledene oxide II & 1668 & - & 1.88 & $b, c$ \\
\hline
\end{tabular}




\begin{tabular}{|c|c|c|c|c|c|}
\hline \multirow[b]{2}{*}{$\mathbf{R}_{\mathrm{t}}(\min )$} & \multirow[b]{2}{*}{ Compound $^{1}$} & \multicolumn{2}{|c|}{ KI } & \multirow{2}{*}{$\begin{array}{c}\text { Area } \\
(\%)\end{array}$} & \multirow{2}{*}{ Criteria $^{3}$} \\
\hline & & Calculated $^{2}$ & $\begin{array}{c}\text { Literatur } \\
\text { e }\end{array}$ & & \\
\hline 29.01 & khusinol & 1675 & 1680 & 7.23 & $a, b, c$ \\
\hline 29.72 & pentadecan-2-one & 1702 & 1697 & 16.38 & $a, b, c, d$ \\
\hline 30.38 & geranyl- $\alpha$-terpinene & 1726 & - & 4.46 & $b, c$ \\
\hline 30.78 & eremophilone & 1740 & 1736 & 0.60 & $a, b, c$ \\
\hline 34.98 & heptadecan-2-one & 1904 & 1906 & 5.83 & $a, b, c, e$ \\
\hline 38.73 & manool & 2060 & 2057 & 0.77 & $a, b, c$ \\
\hline 39.63 & $n$-heneicosane & 2100 & 2100 & 2.92 & $a, b, c$ \\
\hline 43.98 & $n$-tricosane & 2299 & 2300 & 6.17 & $a, b, c$ \\
\hline 47.99 & $n$-pentacosane & 2499 & 2500 & 1.10 & $a, b, c$ \\
\hline \multicolumn{6}{|c|}{ Classes of compounds (\%) } \\
\hline \multicolumn{6}{|c|}{ Oxygenated monoterpenes } \\
\hline Aldehyde & & & & & 3.44 \\
\hline Sesquite & e hydrocarbons & & & & 17.24 \\
\hline \multicolumn{6}{|c|}{ Oxygenated sesquiterpenes } \\
\hline Alcohols & & & & & 44.82 \\
\hline Ketones & & & & & 3.44 \\
\hline Epoxides & & & & & 3.44 \\
\hline Diterpen & drocarbons & & & & 3.44 \\
\hline Oxygeno & diterpene & & & & 3.44 \\
\hline \multicolumn{6}{|c|}{ Straight chain aliphatic compounds } \\
\hline Hydrocal & & & & & 10.34 \\
\hline Ketones & & & & & 6.89 \\
\hline Unknow & & & & & 3.44 \\
\hline Total of & ompounds & & & & 99.93 \\
\hline
\end{tabular}

m/z (Rel. Int.): unknown 1: 218(100), 175(98), 147(50), 91(48), 105(40).

${ }^{1}$ Compound listed in order of elution. ${ }^{2}$ Kovats index on an HP-5 MS column, determined experimentally using a homologous series of $n$-alkanes. ${ }^{3}$ Compound identification criteria: (a) calculated KI compared with KI from the Adams book; ${ }^{23}$ (b) comparison of MS with those of database (Shim, Wiley, NIST08, NIST08s libraries and NIST Standard Reference Data; ${ }^{22}$ (c) comparison of $\mathrm{MS}^{23}$ (d) comparison with commercial standard; (e) Souza et al. 2009. ${ }^{34}$

The forty-seven constituents identified Oxygenated sesquiterpenes were the main from leaves are listed in Table 2, constituents (71.25\% of the EO). The main corresponding $95.12 \%$ of the total oil. representatives of this class were spathulenol 
(27.11\%), khusinol (13.04\%), globulol (6.47 $\%)$, cis-guaia-3,9-dien-11-ol (5.98\%) and 2epi- $\alpha$-cedren-3-one (4.69\%). Sesquiterpene hydrocarbons represented $9.62 \%$ of the detected compounds and bicyclogermacrene $(8.52 \%)$ was the major constituent of this class. Among other compounds, small amounts of elemicin (4.32\%), viridiflorol (2.51 $\%)$, muurola-4-10(14)-dien-1- $\beta$-ol (2.39\%), (Z)-14-hydroxy-caryophyllene $(2.35 \%)$ and geraniol acetate $(2.24 \%)$ were detected.

By comparison with previously extracted EO, our analyses confirmed the data reported, where the main compound was $27.5 \%$ and $64.4 \%$ spathulenol in species from Bolivia ${ }^{10}$ and $\mathrm{Cuba},{ }^{27}$ respectively. On the other hand, the main compound in the species occurring in North Brazil $^{9}$ was sesquiterpene bicyclogermacrene (36.5\%), followed by spathulenol (20.5 \%). However, a much smaller amount of spathulenol (3.1\%) was found in the species occurring in Southeast Brazil, ${ }^{11}$ and $\alpha$-pinene ( $26.1 \%$ ) was the major compound, followed by limonene (22.3\%), and bicyclogermacrene $(20.4 \%)$. It is interesting to note that bicyclogermacrene sesquiterpene is the precursor of spathulenol, an oxygenated sesquiterpene that can be formed by enzymatic oxidation of bicyclogermacrene. ${ }^{28}$

Table 2. Chemical constituents of the essential oil from $X$. aromatica leaves

\begin{tabular}{|c|c|c|c|c|c|}
\hline \multirow[b]{2}{*}{$R_{t}(\min )$} & \multirow[b]{2}{*}{ Compound $^{1}$} & \multicolumn{2}{|c|}{ KI } & \multirow{2}{*}{$\begin{array}{c}\text { Area } \\
(\%)\end{array}$} & \multirow[b]{2}{*}{ Criteria $^{3}$} \\
\hline & & Calculated $^{2}$ & $\begin{array}{l}\text { Literatur } \\
\text { e }\end{array}$ & & \\
\hline 14.95 & $\alpha$-terpineol & 1194 & 1188 & 0.47 & $a, b, c$ \\
\hline 15.81 & trans-carveol & 1219 & 1216 & 0.18 & $a, b, c$ \\
\hline 16.92 & geraniol & 1250 & 1252 & 1.73 & $a, b, c$ \\
\hline 19.33 & citronellic acid & 1319 & 1313 & 0.23 & $a, b, c$ \\
\hline 19.40 & methyl geranate & 1321 & 1324 & 0.13 & $a, b, c$ \\
\hline 19.81 & $\delta$-elemene & 1332 & 1338 & 0.16 & a \\
\hline 20.38 & citronellyl acetate & 1349 & 1352 & 0.17 & $a, b$ \\
\hline 21.37 & geraniol acetate & 1377 & 1381 & 2.24 & $a, b, c$ \\
\hline 21.47 & geranic acid & 1380 & 1375 & 0.08 & $b, c, e$ \\
\hline 21.79 & $\beta$-elemene & 1389 & 1390 & $\operatorname{tr}$ & $a, d$ \\
\hline 23.43 & aromadendrene & 1439 & 1441 & 0.09 & a \\
\hline 24.06 & alloaromadendrene & 1459 & 1460 & 0.05 & $a, d$ \\
\hline 24.71 & $(E)$ - $\beta$-ionone & 1479 & 1488 & 0.10 & $a, b$ \\
\hline 24.82 & germacrene D & 1483 & 1485 & 0.46 & $a, b, c$ \\
\hline 25.15 & viridiflorene & 1493 & 1496 & 0.08 & $a, b, c$ \\
\hline 25.33 & bicyclogermacrene & 1499 & 1500 & 8.52 & $a, b$ \\
\hline 25.54 & trans- $\beta$-guaiene & 1505 & 1502 & 0.17 & a \\
\hline 25.96 & cubebol & 1518 & 1515 & 0.09 & $\mathrm{a}$ \\
\hline 25.98 & $\delta$-cadinene & 1519 & 1523 & 0.09 & $a, b$ \\
\hline 26.90 & elemicin & 1548 & 1557 & 4.32 & $a, b$ \\
\hline
\end{tabular}




\begin{tabular}{|c|c|c|c|c|c|}
\hline 27.41 & $(E)$-nerolidol & 1564 & 1563 & 0.73 & $a$ \\
\hline 27.70 & (3Z)-hexenyl benzoate & 1572 & 1566 & 0.93 & $a, b$ \\
\hline 28.02 & spathulenol & 1583 & 1578 & 27.11 & $a, b, c$ \\
\hline 28.25 & globulol & 1590 & 1590 & 6.47 & $a, b, c$ \\
\hline 28.48 & viridiflorol & 1597 & 1592 & 2.51 & $a, b, c$ \\
\hline 28.76 & humulene epoxide II & 1606 & 1608 & 0.43 & a \\
\hline 29.29 & 2-epi- $\alpha$-cedren-3-one & 1625 & 1627 & 4.69 & a \\
\hline 29.44 & 1-epi-cubenol & 1630 & 1628 & 1.23 & a \\
\hline 29.60 & $\begin{array}{c}\text { muurola-4-10(14)-dien-1- } \\
\beta \text {-ol }\end{array}$ & 1636 & 1631 & 2.39 & a \\
\hline 30.06 & cis-guaia-3,9-dien-11-ol & 1652 & 1649 & 5.98 & a \\
\hline 30.29 & $\begin{array}{l}\text { (Z)-14-hydroxy- } \\
\text { caryophyllene }\end{array}$ & 1660 & 1667 & 2.35 & a \\
\hline 30.60 & unknown 1 & 1671 & - & 2.84 & - \\
\hline 30.92 & khusinol & 1682 & 1680 & 13.04 & a \\
\hline 31.32 & $\begin{array}{c}\text { germacra-4(15),5,10(14)- } \\
\text { trien-1- } \alpha \text {-ol }\end{array}$ & 1696 & 1686 & 0.61 & $a, b, c$ \\
\hline 31.50 & cyperotundone & 1702 & 1695 & 1.71 & a, c \\
\hline 31.75 & $\begin{array}{l}\text { 14-hydroxy-4,5-dihydro- } \\
\text { caryophyllene }\end{array}$ & 1711 & 1706 & 0.28 & $a, b$ \\
\hline 32.47 & isobicyclogermacrenal & 1736 & 1734 & 1.32 & $a, b, c$ \\
\hline 33.28 & $\begin{array}{c}\text { 4,14-anhydro-amorpha- } \\
\text { 4,9-diene }\end{array}$ & 1764 & 1756 & 0.16 & a \\
\hline 35.40 & $\begin{array}{l}\text { 6,10,14-trimethyl-2- } \\
\text { pentadecanone }\end{array}$ & 1841 & 1842 & 0.10 & $b, c, f$ \\
\hline 36.58 & 3,4-benzocinnoline & 1886 & - & 0.32 & g \\
\hline 36.98 & $n$-nonadecane & 1901 & 1900 & 0.10 & a \\
\hline 37.56 & carissone & 1923 & 1927 & 0.15 & a \\
\hline 38.61 & caprylic ether & 1963 & - & 0.77 & $b, c$ \\
\hline 39.38 & 1-eicosene & 1993 & 1988 & 0.17 & $a, b$ \\
\hline 40.95 & manool & 2057 & 2057 & 0.96 & $a, b, c$ \\
\hline 42.25 & phytol & 2111 & 2111 & 0.87 & $b, c, h$ \\
\hline 42.91 & unknown 2 & 2138 & - & 0.24 & - \\
\hline 44.20 & 1-docosene & 2192 & 2189 & 0.14 & $a, b, c$ \\
\hline \multicolumn{6}{|c|}{ Classes of compounds (\%) } \\
\hline \multicolumn{6}{|c|}{ Oxygenated monoterpenes } \\
\hline
\end{tabular}


\begin{tabular}{lc}
\hline alcohols & 2.38 \\
acid + acetate ester & 0.36 \\
Sesquiterpene hydrocarbons & 9.62 \\
Oxygenated sesquiterpenes & \\
Alcohols & 62.79 \\
aldehydes & 1.32 \\
ketones & 6.55 \\
epoxides & 0.59
\end{tabular}

Oxygenated diterpenes

$\begin{array}{ll}\text { alcohols } & 1.20\end{array}$

Straight chain aliphatic compounds

$\begin{array}{ll}\text { hydrocarbon } & 0.41\end{array}$

$s$

$\begin{array}{ll}\text { alcohols } & 0.87\end{array}$

$\begin{array}{ll}\text { ketones } & 0.20\end{array}$

$\begin{array}{ll}\text { acids + ether } & 7.58\end{array}$

$\begin{array}{ll}\text { benzenoids } & 1.25\end{array}$

$\begin{array}{ll}\text { Unknown } & 2.84\end{array}$

$\begin{array}{lr}\text { Total of all compounds } & 97.96\end{array}$

m/z (Rel. Int.): unknown 1: 177(100), 123(98), 55(73), 159(69), 91(59). unknown 2: 55 (100), 81 (83), 93 (68), 107 (48), 123 (30).

${ }^{1}$ Compound listed in order of elution. ${ }^{2}$ Kovats Index on DB-5MS column, determined experimentally using a homologous series of $n$-alkanes. ${ }^{3}$ Compound identification criteria: (a) calculated KI compared with KI from the Adams book; ${ }^{23}$ (b) comparison of MS with those of database (Shim, Wiley, NIST08, NIST08s libraries and NIST Standard Reference Data; ${ }^{22}$ (c) similarity index with mass spectral database (Shim, Wiley, and Nist Libraries); (d) comparison with commercial standard; (e) Ouamba et al. 2006; $;^{35}$ (f) Smelcerovic et al. 2007; ${ }^{36}$ (g) Rostad et al. 1986; ${ }^{37}$ (h) Kukic et al. 2006. ${ }^{38}$

As for the contribution to the aromatic plant fingerprint, it should be noted that the volatile compounds in different parts of $X$. aromatica differ. Only $\delta$-elemene, germacrene $\mathrm{D}$, bicyclogermacrene, $\delta$ cadinene, spathulenol, globulol, viridiflorol, khusinol, and manool were found in both oils. The latter compound, the major one in flower oil (16.38\%), was not found in the leaf oil. On the other hand, spathulenol, the main compound in leaf oil $(27.11 \%)$, was present as $3.00 \%$ of the flower oil. This difference can be partly explained by the existence of distinct secretory structures in different plant parts. ${ }^{29}$

\subsection{Antimicrobial activity}

The MIC results are listed in Table 3. With regard to the antimicrobial activity of the plant material, MIC values of less than or equal to $100 \mu \mathrm{g} \mathrm{mL}^{-1}$ were characterized as good activity; from 100 to $500 \mu \mathrm{g} \mathrm{mL}^{-1}$ as moderate; from 500 to $1000 \mu \mathrm{g} \mathrm{LL}^{-1}$ as weak; 
and over $1000 \mu \mathrm{g} \mathrm{mL}^{-1}$ as inactive against both Gram-positive and Gram-negative bacteria and yeasts. ${ }^{30}$ In this study, samples displaying a MIC of over $400 \mu \mathrm{g} \mathrm{mL}^{-1}$ against bacteria and of over $2000 \mathrm{\mu g} \mathrm{mL} \mathrm{m}^{-1}$ for yeast were considered inactive.

The flower oil was found to have an inhibitory bacterial effect against $S$. pyogenes (ATCC 12345) (MIC $200 \mu \mathrm{g} \mathrm{mL}^{-1}$ ), S. aureus
(ATCC 29213, 25923 and 43300) (MIC $400 \mu \mathrm{g}$ $\mathrm{mL}^{-1}$ ) and $P$. aeruginosa strains (ATCC 27853 and 14502) (MIC $400 \mu \mathrm{g} \mathrm{mL}^{-1}$ ). However, no activity against $B$. cepacia ATCC 17759 and $P$. acnes ATCC 11827 (MIC $>400 \mu \mathrm{g} \mathrm{mL}^{-1}$ ) was detected. As for its antifungal potential, this oil presented weak activity (MIC $2000 \mathrm{mg} \mathrm{mL}^{-1}$ ) against Candida strains (ATCC 4639 and 13803).

Table 3. Antimicrobial activity of the essential oils of $X$. aromatica flowers and leaves

\begin{tabular}{|c|c|c|c|}
\hline \multirow{3}{*}{ Microorganism } & \multicolumn{3}{|c|}{ MIC $\left(\mu g \mathrm{~mL}^{-1}\right)$} \\
\hline & \multicolumn{2}{|c|}{ Essential Oil } & \multirow{2}{*}{$\begin{array}{c}\text { Reference } \\
\text { Drug }\end{array}$} \\
\hline & Flowers & Leaves & \\
\hline Burkholderia cepacia ATCC 17759 & $>400$ & $>400$ & $5.9^{c}$ \\
\hline Pseudomonas aeruginosa ATCC 14502 & 400 & 400 & $5.9^{c}$ \\
\hline Pseudomonas aeruginosa ATCC 27853 & 400 & 400 & $>5.9^{c}$ \\
\hline Staphylococcus aureus ATCC 25923 & 400 & 400 & $0.37^{d}$ \\
\hline Staphylococcus aureus ATCC 43300 & 400 & 400 & $2.95^{d}$ \\
\hline Staphylococcus aureus ATCC 29213 & 400 & 400 & $0.74^{d}$ \\
\hline Streptococcus pyogenes ATCC 12345 & 200 & 100 & $0.37^{d}$ \\
\hline Candida albicans ATCC 4639 & 2000 & 500 & nt \\
\hline Candida tropicalis ATCC 13803 & 2000 & 2000 & nt \\
\hline Candida krusei ATCC $6258^{\mathrm{a}}$ & nt & nt & $2.0^{\mathrm{e}}$ \\
\hline Candida parapsilosis ATCC $22019^{a}$ & nt & nt & $1.0^{\mathrm{e}}$ \\
\hline Propionibacterium acnes ATCC 11827 & $>400$ & $>400$ & nt \\
\hline Bacteroides fragilis ATCC $25285^{a}$ & nt & nt & $1.47^{\mathrm{b}}$ \\
\hline Bacteroides thetaiotaomicron ATCC $29741^{\text {a }}$ & nt & nt & $2.95^{b}$ \\
\hline
\end{tabular}

${ }^{a}$ control strains; ${ }^{b}$ metronidazole; ${ }^{c}$ streptomycin; ${ }^{d}$ penicillin; ${ }^{e}$ amphotericin; nt: not tested

The leaf oil showed good activity $(100 \mu \mathrm{g}$ $\mathrm{mL}^{-1}$ ) against $S$. pyogenes (ATCC 12345). For other bacteria, the MIC values were moderate $\left(400 \mu \mathrm{g} \mathrm{mL}{ }^{-1}\right)$, and no activity was detected against B. cepacia ATCC 17759 and P. acnes ATCC 11827 (MIC > $400 \mu \mathrm{g} \mathrm{mL}{ }^{-1}$ ). Although previous studies have reported MIC values of $20 \mathrm{mg} \mathrm{mL}^{-1}$ against $S$. aureus and C. albicans, and no activity against $P$. aeruginosa $(\mathrm{MIC}>20$ $\left.\mathrm{mg} \mathrm{mL}^{-1}\right),{ }^{10}$ in this study we obtained MIC values of $400 \mu \mathrm{g} \mathrm{mL}^{-1}$ against $S$. aureus and $P$. aeruginosa, and $500 \mu \mathrm{g} \mathrm{mL}^{-1}$ against $C$. albicans. Although spathulenol is present in similar proportions in $X$. aromatica leaf oils from Brazil, studied here, and Bolivia, ${ }^{10}$ the other identified components differ widely. This may explain the different MIC values found in the two cases.

The significant antimicrobial activity of the EO from $X$. aromatica leaves can probably be 
explained by the fact that the leaves contain a larger amount of oxygenated sesquiterpenes $(71.25 \%)$ than the flowers $(51.70 \%)$. This finding has been reported in previous studies, which demonstrated that the presence of an oxygenated function in terpene enhances its antibacterial activity. ${ }^{31,32}$

In addition, some studies report that whole EO exhibits better antibacterial activity than its individual components, thus suggesting that the minor compounds are essential to the activity due to the synergistic effect or potentiating influence of the various molecules. ${ }^{33}$

\section{Conclusion}

The analysis of EO from $X$. aromatica revealed significant variations in the chemical composition. Sesquiterpenes represented the main constituents $(68.96 \%$ and $80.87 \%$ of flowers and leaves, respectively). Thus, this study offers the first report about the chemical composition and antimicrobial activity of the EO from $X$. aromatica flowers and contributes to the body of knowledge about this species. In vitro antimicrobial activity of EOs was evaluated against microorganisms that cause skin lesions and showed moderate activity against $P$. aeruginosa, S. aureus and S. pyogenes. As for antifungal properties, the leaves showed moderate activity against $C$. albicans. Sesquiterpenes have been reported in the literature by possess antimicrobial activity and this characteristic may the responsible to the biological activity observed from the EOs. However, further research is needed to draw the association between these compounds and microorganisms evaluated.

\section{Acknowledgements}

The authors thank CNPq (grant no. 563286/2010-5) and FAPEG (grant no. 200910267000366) for their financial support.

\section{References}

${ }^{1}$ Moreira, I. C.; Roque, N. F.; Vilegas, W.; Zalewski, C. A.; Lago, J. H. G.; Funasaki, M. Genus Xylopia (Annonaceae): chemical and biological aspects. Chemistry and Biodiversity. 2013, 10, 1921. [CrossRef] [PubMed]

${ }^{2}$ Fournier, G.; Leboeuf, M.; Cavé, A. Annonaceae Essential Oils: A Review. Journal of Essential Oil Research 1999, 11, 131. [CrossRef]

${ }^{3}$ Lago, J. H. G.; Moreira, I. C.; Tanizaki, T. M.; Moreno, P. R. H.; Roque, N. F.; Limberger, R. P.; Apel, M. A.; Henriques, A. T. Mono and sesquiterpenes from the leaf essential oil of Xylopia brasisiensis Spreng. (Annonaceae). Journal of essential oil research 2003, 15, 406. [CrossRef]

${ }^{4}$ Fournier, G.; Hadjiakhoondi, A.; Charles, B.; Leboeuf, M.; Cavé, A. Volatile constituents of Xylopia nitida leaf oil. Planta Medica. 1993, 59, 185. [CrossRef]

${ }^{5}$ Ferraz, R. P. C.; Cardoso, G. M. B.; Silva, T. B.; Fontes, J. E. N.; Prata, A. N.; Carvalho, A.; Moraes, M. O.; Pessoa, C.; Costa, E.V.; Bezerra, D. P. Antitumour properties of the feaf essential oil of Xylopia frutescens Aubl. (Annonaceae). Food Chemistry 2013, 141, 196. [CrossRef] [PubMed]

${ }^{6}$ Tavares, J. F.; Silva, M. V. B.; Queiroga, K. F.; Martins, R. M.; Silva, T. M. S.; Camara, C. A.; Agra, M. F.; Barbosa-Filho, J. M.; Silva, M. S.; Marques, M. O. M. Composition and molluscicidal properties of essential oils from leaves of Xylopia langsdorffiana A. St. Hil. Et Tul. (Annonaceae). Journal of essential oil research 2007, 19, 282. [CrossRef]

7 Pontes, W. J. T.; Oliveira, J. C. S.; Câmara. C. A. G.; Gondim Jr., M. G. C.; Oliveira, J. V. Schwartz, M. O. E. Atividade acaricida dos óleos essenciais de folhas e frutos de Xylopia sericea sobre o ácaro rajado (Tetranychus urticae KOCH). Química. Nova 2007, 30, 838. [CrossRef]

${ }^{8}$ Stashenko, E. E.; Jaramillo, B. E.; Martínez, J. R. Analysis of volatile secondary metabolites from Colombian Xylopia aromatica (Lamarck) by different extraction and headspace 
methods and gas chromatography. Journal of Chromatography A 2004, 1025, 105. [CrossRef] [PubMed]

${ }^{9}$ Maia, J. G. S.; Andrade, E. H. A.; Silva, A. C. M.; Oliveira, J.; Carreira, L. M. M.; Araújo, J. S. Leaf volatile oils from four Brazilian Xylopia species. Flavour and Fragrance Journal 2005, 20, 474. [CrossRef]

${ }^{10}$ Fournier, G.; Hadjiakhoondi, A.; Charles, B.; Fourniat, J.; Leboeuf, M.; Cavé, A. Chemical and biological studies of Xylopia aromatica stem bark and leaf oils. Planta Medica 1994, 60, 283. [CrossRef] [PubMed]

11 Lago, J. H. G.; Ávila Jr, P.; Moreno, P. R. H.; Limberger, R. P.; Apel, M. A.; Henriques,A. T. Analysis, comparison and variation on the chemical composition from the leaf volatile oil of Xylopia aromatica (Annonaceae). Biochemical Systematics and Ecology. 2003b, 31, 669. [CrossRef]

12 Jürgens, A.; Webber, A. C.; Gottsberger, G. Floral scent compounds of Amazonian Annonaceae species pollinated by small beetles and thrips. Phytochemistry 2000, 55, 551. [CrossRef] [PubMed]

${ }^{13}$ Andrade, E. H. A.; Silva, A. C. M.; Carreira, L. M. M.; Oliveira, J.; Maia, J. G. S. Essential oil composition from leaf, fruit and flower of Xylopia aromatica (Lam.) Mart. Journal Essential Oil Bearing Plants 2004, 7, 151. [CrossRef]

14 Walker, M. J.; Barnett, T. C.; McArthur, J. D.; Cole, J. N.; Gillen, C. M.; Henningham, A.; Sriprakash, K. S.; Sanderson-Smith, M. L.; Nizet, $V$. Disease manifestations and pathogenic mechanisms of group A Streptococcus. Clinical Microbiology Reviews. 2014, 27, 264. [CrossRef] [PubMed]

${ }^{15}$ Franklin, D.; Lowy, M. D. Staphylococcus aureus infections. The New England Journal of Medicine 1998, 339, 520. [CrossRef] [PubMed]

${ }^{16}$ Omar, N.; H. Raouf, A. E.; Okasha, H.; Nabil, N. Microbiological assessment of Burkholderia cepacia complex (Bcc) isolates in Alexandria Main University Hospital. Alexandria Journal of Medicine 2015, 51, 41. [CrossRef]
17 Soheili, V.; Bazzaz, B. S. F.; Abdollahpour, N.; Hadizadeh, F. Investigation of Pseudomonas aeruginosa quorum-sensing signaling system for identifying multiple inhibitors using molecular docking and structural analysis methodology. Microbial Pathogenesis 2015, 89, 73. [CrossRef] [PubMed]

${ }^{18}$ Zou, Y.; Nair, S. K. Molecular basis for the recognition of structurally distinct autoinducer mimics by the Pseudomonas aeruginosa LasR Quorum sensing signaling receptor. Chemistry \& Biology. 2009, 16, 961. [CrossRef] [PubMed]

${ }^{19}$ Castro, R. D.; Lima, E. O. Anti-candida activity and chemical composition of Cinnamomum zeylanicum blume essestial oil. Brazilian. Archives of Biology and Technology. 2013, 56, 749. [CrossRef]

${ }^{20}$ Whibley, N.; Gaffen, S. L. Beyond Candida albicans: mechanism of immunity to nonalbicans Candida species. Cytokine 2015, 76, 42. [CrossRef] [PubMed]

${ }^{21}$ Quiroga, E. D.; Cormick, M. P.; Pons, P.; Alvarez, M. G.; Durantini, E. N. Mechanistic aspects of the photodynamic inactivation of Candida albicans induced by cationic porphyrin derivatives. European Journal of Medicinal Chemistry 2012, 58, 332. [CrossRef] [PubMed]

${ }^{22}$ Data NIST Standard Reference. Available online:

<http://webbook.nist.gov/chemistry/nameser.html>. (accessed on $15^{\text {th }}$ November 2017).

${ }^{23}$ Adams, R. P.; Identification of essential oil components by Gas Chromatography/Mass Spectrometry, Allured Publishing Corporation: Carol Stream, 2007.

${ }^{24}$ Moraes, T. S; Leandro, L. F.; Silva, L. O.; Santiago, M. B.; Souza, A. B.; Furtado, R. A.; Tavares, D. C.; Veneziani, R. C.; Ambrósio, S. R.; Bastos, J. K.; Martins, C. H. In vitro evaluation of Copaifera oblongifolia oleoresin against bacteria causing oral infections and assessment of its cytotoxic potential. Current Pharmaceutical Biotechnology 2016, 17, 894. [CrossRef] [PubMed]

${ }^{25}$ Souza, C. M.; Pereira Jr., S. A.; Moraes, T. S.; Damasceno, J. L.; Amorim, M. S.; Dias, H. J.; 
Stefani, R.; Tavares, D. C.; Martins, C. H.; Crotti, A. E.; Mendes-Giannini, M. J.; Pires, R. $\mathrm{H}$. Antifungal activity of plant-derived essential oils on Candida tropicalis planktonic and biofilms cells. Medical Mycology 2016, 54, 515. [CrossRef] [PubMed]

${ }^{26}$ Sarker, S. D.; Nahar, L.; Kumarasamy, Y. Microtitre plate-based antibacterial assay incorporating resazurin as an indicator of cell growth, and its application in the in vitro antibacterial screening of phytochemicals. Methods 2007, 42, 321. [CrossRef] [PubMed]

27 Pino, J. A. Bello, A.; Urquiola, A.; Garcia, S.; Rosado, A. Leaf oil of Xylopia aromatica (Lam.) Mart. from Cuba. Journal of Essential Oil Research 2000, 12, 751. [CrossRef]

${ }^{28}$ Bülow, N.; König, W. A. The role of germacrene $D$ as a precursor in sesquiterpene biosynthesis: investigations of acid catalyzed, photochemically and thermally induced rearrangements. Phytochemistry 2000, 55, 141. [CrossRef] [PubMed]

${ }^{29}$ Figueiredo, A. C.; Barroso, J. G.; Pedro, L. G.; Scheffer, J. C. Factors affecting secondary metabolite production in plants: volatile components and essential oils. Flavour and Fragrance Journal 2008, 23, 213. [CrossRef]

${ }^{30}$ Bardají, D. K. R.; Reis, E. B.; Medeiros, T. C. T.; Lucarini, R.; Crotti, A. E. M.; Martins, C. H. G. Antibacterial activity of commercially available plant-derives essential oils against oral pathogenic bacteria. Natural Product Research 2016, 30, 1178. [CrossRef] [PubMed]

${ }^{31}$ Naigre, R.; Kalck, P.; Roques, C.; Roux, I.; Michel, G. Comparison of antimicrobial properties of monoterpenes and their carbonylated products. Planta Medica 1996, 62, 275. [CrossRef] [PubMed]

${ }^{32}$ Dorman, H. J. D.; Deans, S. G. Antimicrobial agents from plants: antibacterial activity of plant volatile oils. Journal of Applied Microbiology 2000, 88, 308. [CrossRef] [PubMed]

${ }^{33}$ Burt, S. Essential oils: their antibacterial properties and potential applications in foods - a review. International Journal of Food Microbiology 2004, 94, 223. [CrossRef] [PubMed]

${ }^{34}$ Souza, P. P. Cardeal, Z. L.; Augusti, R.; Morrison, P.; Marriott, P. J. Determination of volatile compounds in Brazilian distilled cachaça by using comprehensive twodimensional gas chromatography and effects of production pathways. Journal of Chromatography A 2009, 1216, 2881. [CrossRef] [PubMed]

35 Ouamba, J. M.; Ouabonzi, A.; Ekouya, A.; Bessière, J. M.; Menut, C.; Abena, A. A.; Banzouzi, J. T. Volatile constituents of the essential oil leaf of Lantana salvifolia Jacq. (Verbenaceae). Flavour and Fragrance Journal 2006, 21,158. [CrossRef]

${ }^{36}$ Smelcerovic, A.; Spiteller, M.; Ligon, A. P.; Smelcerovic, Z.; Raabe, N. Essential oil composition of Hypericum L. species from Southeastern Serbia and their chemotaxonomy. Biochemical Systematics and Ecology 2007, 35, 99. [CrossRef]

${ }^{37}$ Rostad, C. E.; Pereira, W. E. Kovats and Lee retention indices determined by gas chromatography/mass spectrometry for organic compounds of environmental interest. Journal of High Resolution Chromatography \& Chromatography Communications 1986, 9, 328. [CrossRef]

${ }^{38}$ Kukić, J.; Petrović, S.; Pavlović, M.; Couladis, M.; Tzakou, O.; Niketić, M. Composition of essential oil of Stachys alpina L. ssp. Dinarica Murb. Flavour and Fragrance Journal 2006, 21, 539. [CrossRef] 